\title{
Between film and photography: the bubble of blood in 'The Family of Disorder'
}

Article

Accepted Version

Elduque Busquets, A. (2019) Between film and photography: the bubble of blood in 'The Family of Disorder'. Screen, 60 (1). pp. 148-159. ISSN 1460-2474 doi:

https://doi.org/10.1093/screen/hjy069 Available at https://centaur.reading.ac.uk/81676/

It is advisable to refer to the publisher's version if you intend to cite from the work. See Guidance on citing.

To link to this article DOI: http://dx.doi.org/10.1093/screen/hjy069

Publisher: Oxford University Press

All outputs in CentAUR are protected by Intellectual Property Rights law, including copyright law. Copyright and IPR is retained by the creators or other copyright holders. Terms and conditions for use of this material are defined in the End User Agreement.

\section{www.reading.ac.uk/centaur}

\section{CentAUR}

Central Archive at the University of Reading

Reading's research outputs online 


\section{Between Film and Photography: The Bubble of Blood in The Family of Disorder ${ }^{1}$}

Founded in 1970, within the context of the military dictatorship, the film company Belair was one of the most radical experiments in the history of Brazilian cinema. Headed by filmmakers Rogério Sganzerla and Júlio Bressane and the actor Helena Ignez, Belair attempted to cultivate a cinema in the spirit of Tropicalism, even though its participants were not officially attached to this movement. Indeed, while Sganzerla refused to be pigeonholed as a tropicalist, he nevertheless admitted to some affinities with its aesthetic project. ${ }^{2}$ Overall, the works produced by Belair were attuned to Tropicália through their parodies of genre filmmaking, a carnivalesque celebration of the body, and a profound investment in subversive politics. This challenging exploration of film language quite often implies an approximation to the interaction between cinema and other arts, particularly popular genres such as vaudeville theatre and carnival songs. In this article I intend to explore the convergence of intermedial exploration and political discourse in A família do barulho/The Family of Disorder (Júlio Bressane, 1970), one of the most important films produced by Belair. By focusing on three shots placed at the end of the film, I will analyse how an exploration of the borders between photography and cinema was used to denounce the ideological and physical repression of the human body by the military dictatorship.

There is no agreement about Belair's exact life span. In a 1990 interview, Sganzerla reported that the company existed from March to September. However, I subscribe to the thesis of film critic Jairo Ferreira, who claims that Belair lasted from January to March. This is consistent with an undated document on The Family of Disorder by Júlio Bressane which states that the film was shot and edited in February. ${ }^{3}$ In that three-month period, the Rio de Janeiro-based company produced six films: Sganzerla’s Copacabana mon amour/Copacabana, My Love, Sem essa, Aranha/No Way, Spider and Carnaval na 
lama/Carnival in the Mud, and Bressane's The Family of Disorder, Cuidado, madame/Lady Beware and Barão Olavo, O Horrível/Baron Olavo, The Horrible. Bressane adds here the lost making-of film A miss e o dinossauro/The Beauty Queen and the Dinosaur, directed together with Sganzerla. ${ }^{4}$ The film exhibitor Severiano Ribeiro, who had contributed to the expansion of the Brazilian film industry some decades before, donated a significant sum of money to the enterprise, ${ }^{5}$ but production was organised in a family-style scheme, where some regular performers (Helena Ignez, Guaracy Rodrigues) were at the same time part of the crew. This radical departure from standard industrial structures allowed Sganzerla and Bressane to further develop the narrative and formal experiments of their previous features, most notably Sganzerla's $O$ bandido da luz vermelha/The Red Light Bandit (1968) and A mulher de todos/The Woman of Everyone (1969), and Bressane's Cara a cara/Face to Face (1967), O anjo nasceu/The Angel is Born (1969) and Matou a família e foi ao cinema/Killed the Family and Went to the Movies (1969). The films also gave Ignez (whose early career had comprised naturalist roles within the Cinema Novo movement) the chance to continue exploring the Brechtian, playful approach to performance that she had first attempted in Sganzerla's earlier features. ${ }^{6}$

The running time of the various Belair films fluctuates between an hour and an hour and a half, and their loose narrative structures are often blurred by carnivalesque performances, or dissolved by narrative breaks. However, they share and foreground particular topics, such as violence within the bourgeois family, and between bosses and employees. ${ }^{7}$ In Lady Beware a rebellious maid (Maria Gladys) kills her female employers in what is a political act; in Copacabana, My Love the siblings Sônia Silk (Helena Ignez) and Vidimar (Otoniel Serra) choke his exploitative boss Dr. Grilo (Paul Villaça); No Way, Spider depicts the decadent world of the visionary banker, politician and showman Aranha (Jorge Loredo), who is also executed towards the end of the film; Baron Olavo, The Horrible is a 
parodical horror movie about an old aristocrat (Rodolfo Arena) who is a necrophiliac, defiling the bodies of dead women, and The Family of Disorder shows the power struggles within a dysfunctional family. Finally, the only print of Carnival in the Mud was lost after a screening at the Jeu de Paume in 1992, and few traces of it remain today. ${ }^{8}$ Overall, Belair films showed class differences and the contradictions of the bourgeois family through a sarcastic, cynical lens, and this subversive approach to conservative institutions may have been the reason for the sudden interruption of the enterprise. Indeed, while some of the films were still unfinished, Bressane was told that the military regime had become suspicious about their work, so the team moved into exile in London and their collective project came to an end.

The Family of Disorder was shot over four days in February 1970 and edited that same month. Starring Helena Ignez, Guaracy Rodrigues (Guará) and Kléber Santos, as well as Maria Gladys and the old chanchada ${ }^{9}$ star Grande Otelo, it portrays the quarrels within a family made up of two men (Santos and Guará) and a woman (Ignez). The traditional notion of family is challenged from the outset, because the bonds between them are kept vague ${ }^{10}$ and the plot is not clear at all: the characters argue, dance, have sex and eat, but the only significant narrative moment is when they hire a concubine, which causes the tensions between them to rise. This subversion of the traditional family structure irritated the Brazilian censors, and in 1975 the film was banned. According to one of them, it was a 'stupid portrait of a family, where degeneration attains inconceivable levels in disconnected scenes. Obvious immoral insinuations, rude language and some absolutely unnecessary swearwords, homosexuality, lesbianism and other similar idiocies have led me to decide that it should not be released'. ${ }^{11}$ According to the historical record, there had been some prior screenings (for example, in 1972 the poet Torquato Neto announced a showing in Rio de Janeiro ${ }^{12}$ ), but the 
film was not officially released for public audiences until 1979, when it was screened at the Brasilia Film Festival together with Baron Olavo, The Horrible. ${ }^{13}$

In The Family of Disorder different takes of the same dramatic situation are strewn throughout the film without any apparent narrative justification. Towards the end of the film, this series of rather autonomous images is interrupted to show three striking shots, each one lasting between sixty and ninety seconds (Pictures 1-2-3). In each of them a different character faces the camera, looking at the lens or somewhere beyond it, with an expression of suffering before an unknown, invisible danger. The first image is a medium close-up of Kléber Santos, his eyes fixed on something we cannot see and his body completely paralysed, except for some blinking and some swallowing with difficulty; beneath his left eye a dark stain resembles a black, static tear. The second is a medium close-up of Guará, who looks straight at the camera, until he seems to succumb to something, covers his face with his hands and starts to cry. The last one is a close-up of Helena Ignez, who is staring at the lens in a defiant manner, until she vomits up some bloody saliva and closes her eyes. The characters are speechless, but in the second and third shots the silence is replaced by the 'Finale' of Heitor Villa-Lobos' symphonic suite A floresta do Amazonas, performed in 1959 by the Symphony of the Air \& Chorus and soprano Bidu Sayão.

\section{Pictures 1-2-3}

In terms of both their composition and their soundtrack, these three images seem disconnected from the preceding scenes and the shots that follow. Immediately before them we see Guará having his hair combed by Santos and having a silent conversation with Ignez; Guará preparing a dark liquid; the trunk of a palm tree accompanied by some country music; Ignez sitting on a windowsill accompanied by an Arabic melody, and Ignez walking away 
from Guará on the beach, while he desperately follows her. Directly following these three static images, we return to this scene on the beach, though Guará has stopped following Ignez and is now waving goodbye with his hat. Then we see Ignez walking past a flower pot, happily, accompanied by some upbeat music, and finally there is a clapperboard shot of a dining room scene, supplemented by the sound of a toilet flushing. The film ends here. While some connections could be made between these images and the frontal shots of Santos, Guará and Ignez, there is no obvious link and this series remains somehow isolated. However, what is at stake here is not the disconnection with previous or later images, but the fact that, while most of the shots in The Family of Disorder are rather autonomous, these three clearly share similar composition and content. Their structure as a series thus gives them a conclusive, transcendent status that most of the images in the film do not possess. The shots that follow these static shots seem to be an irreverent twist to undermine their relevance, a common strategy in certain Brazilian films of that time, ${ }^{14}$ but nevertheless their singularity and their place within the film as a whole turn them into aesthetic keystones to help us interpret The Family of Disorder.

By posing motionless in front of the camera, Santos, Guará and Ignez seem ready to be photographed. Photography is an important element in The Family of Disorder, while it is not used in any other work in the whole Belair production. At certain moments throughout the film, a series of photographs that legitimise social institutions (such as the army and the family) interrupt the loose development of the plot (Pictures 4-5-6). In these images characters from different ages pose in front of the camera in a formal, structured manner, one that establishes a strong contrast with the carnivalesque domestic scenes in the rest of the film. 


\section{Pictures 4-5-6}

However, the first image of the film shows Santos, Ignez and Guará posing in front of the camera, as still and formal as the people in those official photographs. The image appears again some minutes later, after some shots from a car and home movies of children, a maid and old people playing cards, which were filmed by Bressane when he was a teenager. ${ }^{15}$ The three characters in this image are so static that only a few details reveal to us that they are being filmed and are not in a still. According to Estevão de Pinho Garcia, this composition is reminiscent of both the portraits of traditional families and the early-twentieth-century filmes de cavação ('digging films'), where landowners, politicians and industrialists flaunted their status, sometimes by posing motionless with their relatives, as if they were waiting to be photographed. ${ }^{16}$ Considering the expansive, loutish, almost animal-like behaviour of the family during the rest of the film, here it seems as if they were being forced to imitate those old, official photographs, in order to domesticate their bestial dysfunctionalities by means of a particular visual organisation.

\section{Picture 7}

The parody of official photographs that this image entails is reminiscent of the cover of the album Tropicália ou Panis et Circensis (1968), photographed by Olivier Perroy and designed by Rubens Gerchman, which was a response to The Beatles'Sgt. Pepper's Lonely Hearts Club Band. ${ }^{17}$ Like Perroy's photo, Bressane's image mocks the framing and arrangement of traditional family photos with kitsch clothing and some unexpected postures, such as Ignez with her legs wide opened. In addition, the old photographs and the reference 
to filmes de cavação accord with Bressane's acknowledgement of having taken his inspiration from early cinema. In a typescript entitled 'Cinema do Barulho: Família Inocente', Bressane wrote that

Família do barulho is my 'Little Shop of Horrors', though the dream-ship has no port, it's Edison, Heiss, Sennet and Griffith and his two-minute reels. It's the cycle of Recife ${ }^{18}$ and very much Fragmentos da vida ${ }^{19}$... a forgotten tradition. Many times an archaeological work is better than an invention, and often resurrection is more important than creation... ${ }^{20}$

In the same vein as Bressane, Ignez has referred to a silent masterpiece, Dreyer's La Passion de Jeanne d'Arc/The Passion of Joan of Arc (1928), to explain her performance at the end of The Family of Disorder. ${ }^{21}$ Indeed, early and silent cinema are major inspirations for the film, its home movies and non-narrative performances being reminiscent of everyday situations and vaudeville routines filmed at the turn of the century. In a similar way to early cinema, works by Bressane approach film as an impure, mixed art, an idea he has highlighted many times both in his films (which often establish a dialogue with Brazilian music or literature) and in his written essays. Indeed, when commenting on his 1989 adaptation of Father Vieira's Sermões, he stated:

I 'think' cinema, and I wish to inscribe myself in a tradition of artists that 'think' their creative outputs as extremely sensitive intellectual organisms placed at the border of all arts, sciences and life. [...] To circulate from poetry to music, from painting to literature, from cinema to everything else: this is the movement of contradictions. ${ }^{22}$ 
In her study of the relation between cinema, human body and the other arts, Brigitte Peucker quotes from early film theory to claim that the possibility of reproducing movement created not only great anticipation, but also an uncanny feeling associated with death. Following Georg Lukács, who considered movement to be the essence of cinema, she says that 'cinematic representations of the human body were adjudged to be unmetaphysical and soulless, to constitute one-dimensional creatures whose life is one of pure surface' ${ }^{23}$ On the other hand, Peucker stresses cinema's mixed, impure status, describing it as 'a latecomer' that is 'placed precariously between the sister arts of literature and painting especially'. ${ }^{24}$ Thus throughout her book she explores the filmic materialization of that uneasy, deathly feeling in the interaction between cinema and other arts, and places this interaction within the human body, whose dynamics and transformations reveal the influence of either literature or painting. ${ }^{25}$ By providing examples from different periods ranging from German Expressionism to works by Rainer Werner Fassbinder and Peter Greenaway, she shows that this uncanny feeling often emerges through still images and pictorial shots, because the absence of movement within a dynamic context is associated with death.

Raymond Bellour highlights similar ideas when analysing the role of the morgue and the wax museum as dispositifs that preceded cinema during the nineteenth century. He notes that both anticipated the movement of cinema from the immobility of death: while the morgue exhibited corpses, the wax museum is closely linked in its origins with the guillotine, because Madame Tussaud crafted death masks for its victims during the French Revolution before moving to London and founding her famous museum. At the end of the century, cinema's reproduction of movement aimed to overcome this mortuary stillness of visual representation, even though this same stillness constituted its raw material: cinema is in fact composed of a series of still frames whose immobility is concealed by movement, and only revealed when the film stops on a specific frame. ${ }^{26}$ 
The shots of Kléber Santos, Guará and Helena Ignez towards the end of The Family of Disorder seem to evoke all these old forms of visual representation. Firstly, they work in the same way as the family portrait of these three characters at the beginning of the film, which was a parody of the filmes de cavação: the bodies are forcibly immobilised by a social imperative which attempts to hide or regulate the disorder of the community. Both the family photo and the final shots have an intermedial quality that lies between the stillness of photography and the movement of cinema, constituting a battlefield between two oppositional impulses: a regulation of the body which imposes a visual logic based on stillness, and the freedom of this same body to walk, dance and shout without restrictions. However, there is a crucial difference between them: while the initial family portrait mimicked the distribution of characters in old group photos, the three final images seem inspired by gloomier influences. Their structure, organised into a series of individual shots, as well as their frontal composition and the suffering expressions of the characters, are reminiscent of police mug shots, or even of prisoners preparing to be executed by firing squad. The photographic stillness is therefore not only a protocol or an institutional requirement, it is also an imposed imprisonment which suggests political repression. A later work, Antônio Manuel's short film Loucura e Cultura/Madness and Culture (1973), would emphasise this idea by placing Rogério Duarte, Lygia Pape, Caetano Veloso and Hélio Oiticica in front of the camera as if in mug shots, while in the soundtrack we hear a 1968 debate about Brazilian culture and the French anthem La Marseillaise. ${ }^{27}$

Bellour's foundational dispositifs are also suggested in this space between photography and cinema. The stillness of Santos, Guará and Ignez before the camera makes them look like exhibited corpses or wax figures, far away from the noisy, funny buffoons they once were. However, they are not completely dead, because the moving image guarantees that a single gesture as insignificant as a blink might still emerge as a proof of life. 
This struggle between the stillness of death and the movement of life reminds us of Peucker's comments on the tableau vivant in Goethe's Elective Affinities: 'tableau vivant plays on two related effects: the arrested motion of freezing — hence death — of the human body on the one hand, and the embodiment or bringing to life of the inanimate image on the other' ${ }^{28}$ Neither dead nor alive, the ghostly condition of the three characters also contributes to the political discourse outlined above: deathly repression is no longer an external menace that hovers over the prisoners, but an infectious agent that has already taken control of their bodies, draining them of their vitality. They are living corpses staring into the camera.

Tropicalist poet Torquato Neto once wrote that in The Family of Disorder 'each shot exists on its own and after its incompleteness' ${ }^{29}$ Indeed, the abovementioned intermedial space between photography/repression/death, on the one hand, and cinema/liberation/life, on the other, is the result of the length of these three takes. Time challenges the photographic stillness and at the same time reinforces it, enabling us to travel between photography and cinema and their associated meanings. Moreover, what really stands out here is the actual effect of time on the bodies of Santos, Guará and Ignez, their physical strength, and the audience's in the face of their suffering. While stillness seems to be the incarnation of regulation and death, the intermedial space created between photography and cinema records the efforts of the performer before them, granting those efforts a material consistency that the spectator is also made to endure. Santos' dark tear, Guará's sobbing and Ignez's bloody drool act as particular symptoms of the performers' distress and attest to the defeat of the subversion overall, be it political or aesthetic. Out of the three, the close-up of Helena Ignez vomiting blood and closing her eyes most demands further analysis, because its connection with other Brazilian films of the period also attests to its relevance to the political context. In her work with Rogério Sganzerla and in the other Belair films, Ignez practiced a wide variety of performance styles, to the extent that in the latter, according to Stephen Berg, 
'character composition becomes movement analysis'. ${ }^{30}$ Given the carnivalesque quality of those films, it makes sense to invoke here Mikhail Bakhtin's grotesque body, which is 'a body in the act of becoming. It is never finished, never completed; it is continually built, created, and builds and creates another body'. ${ }^{31}$ The main feature of this body is the mouth, which dominates everything else, to the point that 'the other features are only a frame encasing this wide-open bodily abyss' ${ }^{32}$ Indeed, Ignez's mouth in The Red Light Bandit, The Woman of Everyone and the Belair films is a performance playground, a space for continuous experimentation: she chews gum and kisses, smokes and growls, bites and slides a knife along her tongue. Sometimes this celebratory, bacchic mouth also articulates a crisis: in No Way, Spider she makes herself vomit, again and again, and in Baron Olavo, The Horrible she hardly speaks, but in certain shots widens her mouth as if she were trying to cry, though the only thing we hear is a strong wind, which seems to cover her despair.

Overall, abject images were a key visual element of Brazilian experimental films at that time, including aggressive ingestion, hysterical weeping, vomiting and bloody saliva. ${ }^{33}$ The shot in The Family of Disorder is part of this constellation, but develops it somewhat by introducing paralysis to this repertoire of grotesque movements. According to Helena Ignez, 'the shot was of haemoptysis, and I felt like it was cinema's haemoptysis, with all that wheezing' ${ }^{34}$ This statement, which could be understood in terms of the borders between cinema and photography that we have explored above, could also refer to the extreme contrast between this close-up and her performance in the rest of the film, where she sings, yells at the other characters, eats a banana, makes farting sounds and growls like a lion. In a way, the paralysis of her face at the end of The Family of Disorder counteracts the vital, experimental, grotesque energy of that film, and her mouth is the perfect place to display it for the last time, before she closes her eyes. This was not her last work for Belair, but it 
makes sense to consider it as a crisis point that brings together that extreme experimentation and, at the same time, the subsequent repression that forced her and her colleagues into exile.

In addition, there seems to be a more overarching meaning embedded in the image, suggesting not only an interpretation related to Ignez's career, but also to Brazilian culture and politics in general. Two contemporary Brazilian films, particularly Gustavo Dahl's $O$ bravo guerreiro/The Brave Warrior (1968) and Joaquim Pedro de Andrade's Macunaíma (1969), also associate the mouth with death in their final images, and both also feature a dichotomy between stillness and movement as a way of mediating this coupling. The former finishes with a still image (though not a freeze frame) of a disenchanted left-wing politician with a gun barrel in his mouth, standing in front of a mirror. In the latter, blood emerges from the depths of a pond where the main character is being devoured by a cannibal goddess, while the soundtrack plays the military anthem 'Desfile aos heróis do Brasil', by Heitor VillaLobos. In the first case, the mouth is the place of a whispered suicide. In the second, the blood emerges and expands as if it were inspired by nationalistic music, and it does so as if the pond were a big mouth which had just swallowed the man. In both cases, the closing image refers to the character but also stands for a broader allegory of Brazil. This is particularly obvious in the case of Macunaima, where an anthem about national heroes is played over an image that evokes a Brazilian flag; ${ }^{35}$ the film as a whole constitutes what Ismail Xavier calls an 'allegory of underdevelopment', an 'effort towards an encompassing vision, towards a "state of the nation" discourse' which was shared by many films in the 1960s, from Glauber Rocha's works to the features by Sganzerla and Bressane. ${ }^{36}$ It is not clear if the image of Helena Ignez at the end of The Family of Disorder references those previous images, an allusion which would be attuned with the complex relationship that Bressane and Sganzerla had with Cinema Novo. While they acknowledged some of the movement's virtues, at the same time were very critical of its commercial 
acceptance of the film market. ${ }^{37}$ In any case, the three shots are similar in their allegorical approach to politics. The image of Helena Ignez at the end of The Family of Disorder proposes a kind of fusion of the final images of The Brave Warrior and Macunaima: the stillness of the first is combined here with the viscous motion of the second. In all three cases, the mouth is a black hole in the scene and on the screen that leads towards something invisible: the future death of the politician, the actual death of Macunaíma, and the supposed death of Ignez in The Family of Disorder. In this latter case an allegorical reading is also possible. Seeing Ignez's bloody mouth as a Brazilian flag might seem an exaggeration, but the use of Villa-Lobos' music could justify such an interpretation in national terms, or even in relation to Glauber Rocha's cultural project, which used the music of Villa-Lobos extensively. ${ }^{38}$

This is why this image could also be aligned with Xavier's concept of 'allegories of underdevelopment', even though he does not include Belair films as one of his case studies. According to him, these allegories

condense the filmmakers' response both to the vicissitudes of a social project and to the crisis of the cinema itself. In their confrontation with the Brazilian conjuncture, the films analysed express the passage from the promise of happiness to the contemplation of hell that marked their historical moment, a passage that could not foster the production of a harmonious art; rather, it could only inspire an art that, internalizing history, recognized flaws and failures. ${ }^{39}$

In The Family of Disorder, the uncertain intermedial space between photography and film provides the allegorical fragmentation, the resistance to a totality in order to express the catastrophe of a utopian social project. This was a project that Belair shared with 
Tropicalism: the liberation of the body and the relaxation of family structures, represented by Ignez's frantic, playful figure. The bloody drool on her face would embody, therefore, the allegory of that political, cultural and artistic failure against which Bressane as a filmmaker and Ignez as an actress were powerless. However, even as a sign of defeat, the materiality of the bloody saliva gives the image a viscous, unstable quality which is more attuned to tropicalist experiments than to repressive puritanism. It represented the last cry of Tropicália's carnival, a carnival that, at that precise moment, was sentenced to death.

\footnotetext{
${ }^{1}$ Previous versions of this paper were presented at the $26^{\text {th }}$ Screen Studies Conference (University of Glasgow, $24^{\text {th }}-26^{\text {th }}$ June, 2016), the Universidade Federal do Espírito Santo $\left(9^{\text {th }}\right.$ June, 2017) and the research seminar of Grupo Cine\&Arte (Universidade Tuiuti do Paraná, $29^{\text {th }}$ September, 2017). I am grateful to the organisers of these events and to the attendants for their valuable feedback.

${ }^{2}$ See Marcos Faerman, 'Ele quer destruir o cinema. Você pode gostar do seu filme?', interview held on $15^{\text {th }}$ December, 1969; included in Roberta Canuto (ed.), Rogério Sganzerla - Encontros (Rio de Janeiro: Beco do Azougue, 2007), pp. 40-45.

${ }^{3}$ See Susana Schild, 'Belair, 20 anos depois', Jornal do Brasil, September 17 ${ }^{\text {th }}, 1990$; included in Canuto, Rogério Sganzerla - Encontros, pp. 120-123. Jairo Ferreira, Cinema de Invenção (Rio de Janeiro: Beco do Azougue, 2016), p. 30. Júlio Bressane, Cinema do Barulho: Família Inocente. Typescript document, undated. Available at Memória da Censura no Cinema Brasileiro, 1964-1988:
}

http://www.memoriacinebr.com.br/arquivo.asp?0120088I00401 [accessed: $16^{\text {th }}$ January, 2018]

${ }^{4}$ See 'Júlio Bressane: Cinema inocente', in Ruy Gardnier (ed.), Retrospectiva Júlio Bressane: Cinema inocente (São Paulo: Centro Cultural Banco do Brasil, 2002), p. 14. In 
2005 Helena Ignez recovered this project and directed a short documentary with the same title in which she used old archival images to pay homage to Belair.

${ }^{5}$ Ibid., p. 13.

${ }^{6}$ For an analysis of the performance style of Helena Ignez in Copacabana, My Love, see Anna Karinne Martins Ballalai, 'El ‘actor-en-acto': la dialéctica 'actor/personaje’ en la película Copacabana mon amour (1970) de Rogério Sganzerla', in Mónica Villarroel (ed.), Memorias y representaciones en el cine chileno y latinoamericano (Santiago de Chile: LOM; Centro Cultural la Moneda; Cineteca Nacional de Chile, 2016), pp. 155-164.

${ }^{7}$ See Estevão de Pinho Garcia, 'Esa es violenta: las películas de Júlio Bressane hechas en la productora Belair', ibid., pp. 145-154.

${ }^{8}$ The remaining images show city life, Helena Ignez taking photos at the zoo and her meeting with a man who plays the guitar and threatens her with a knife before becoming her friend.

${ }^{9}$ Chanchadas were Brazilian popular music comedies from the 1930s, 40s and 50s, mostly produced in Rio de Janeiro and often featuring the star system from the vaudeville theatre.

${ }^{10}$ Garcia, 'Esa es violenta', p. 149.

${ }^{11}$ Original: 'Como retrato absurdo de uma família, onde a degeneração atinge níveis inconcebíveis, em cenas desconexas. Insinuações claras de imoralidade, linguagem chula e alguns palavrões totalmente desnecessários, homossexualismo, lesbianismo e outras idiotices do mesmo calibre levam-me a opinar, digo, opinar pela NÃO LIBERAÇÃO.' (my translation) J. Antônio S. Pedroso, 'Parecer de Censura n 2161/75', 24 ${ }^{\text {th }}$ March, 1975. Available at Memória da Censura no Cinema Brasileiro, 1964-1988: http://www.memoriacinebr.com.br/arquivo.asp?0120088C00401 [accessed: $16^{\text {th }}$ January, 2018] 
${ }^{12}$ Torquato Neto, 'Hoje: a família do barulho', Geléia Geral, Última Hora, 26 ${ }^{\text {th }}$ February

1972. Available at Memória da Censura no Cinema Brasileiro, 1964-1988:

http://www.memoriacinebr.com.br/arquivo.asp?0120088I002 [accessed: 16 ${ }^{\text {th }}$ January, 2018]

13 'Bressane faz "Barulho" com "Olavo", Correio Braziliense, 25 th September 1979.

Available at Memória da Censura no Cinema Brasileiro, 1964-1988:

http://www.memoriacinebr.com.br/arquivo.asp?0120088I001 [accessed: 16 ${ }^{\text {th }}$ January, 2018]

${ }^{14}$ In this regard, see Ismail Xavier's analysis of the end of The Red Light Bandit, whose last two sentences include some moral advice ("Moral of the story: Alone we are worth nothing") and a joking, demystifying answer (“So what?”). Ismail Xavier, Allegories of Underdevelopment: Aesthetics and Politics in Modern Brazilian Film (Minneapolis: University of Minnesota Press, 1997), pp. 102-103.

${ }^{15}$ Gardnier, Retrospectiva Júlio Bressane, p. 10.

${ }^{16}$ Garcia, 'Esa es violenta', p. 149. In the 1920s the pejorative expression 'filmes de cavação' ('digging films') referred to non-fiction films overall, being most of the times assignments from the elites with a propaganda intent. Film critics undermined them for not caring about technical, narrative or aesthetical refinement, and for being merely commissioned, 'hunted' or 'dug' images that film operators captured and sold to make money. See Márcia Juliana Santos, 'Cavar, criticar e documentar: aspectos múltiplos da produção fílmica em São Paulo nos anos de 1920 a 1940', História (São Paulo), v. 34, n. 2, July-December 2015, pp. 364382.

${ }^{17}$ Christopher Dunn, Brutality Garden: Tropicália and the Emergence of a Brazilian Counterculture (Chapel Hill, London: University of North Carolina Press, 2001), p. 93. ${ }^{18}$ The Ciclo do Recife (1923-1931) designates the emergence of a solid film production scene in Recife, the capital city of the state of Pernambuco, in the north-east of Brazil. 
${ }^{19} \mathrm{He}$ is referring to the Brazilian silent film Fragmentos da vida/Pieces of Life (José Medina, 1929).

${ }^{20}$ Original: 'Família do Barulho é o meu "Little Shop of Horrors" mas o barco do sonho não tem porto tem é Edison, Heiss, Sennet e o Griffith das bobinas de dois minutos. É o ciclo de Recife e é muito "Fragmentos da Vida"... tradição nossa obnubilada. Muitas vezes um trabalho arqueológico superior uma invenção e frequentemente a ressurreição é mais importante que a criação...' (translation by Lúcia Nagib) Júlio Bressane, Cinema do Barulho: Família Inocente.

${ }^{21}$ See Albert Elduque, 'As Belair went by: An Interview with Helena Ignez', in Stefan Solomon (ed.), Tropicália and Beyond. Dialogues in Brazilian Film History (Berlin: Archive Books and University of Reading, 2017), p. 131.

${ }^{22}$ Original: 'Eu penso o cinema, e aí quero inscrever-me numa tradição de artistas que pensam seu objeto criativo, como um organismo intelectual demasiadamente sensível que faz fronteira com todas as artes, ciências e a vida. [...] Circular da poesia à música, da pintura à literatura, do cinema a tudo, transgredindo os compartimentos convencionais: este é o movimento das contradições.' (translation by Lúcia Nagib) Júlio Bressane, Alguns (Rio de Janeiro: Imago Editora, 1996), pp. 42-43.

${ }^{23}$ Brigitte Peucker, Incorporating Images: Film and the Rival Arts (Princeton: Princeton University Press, 1995), pp. 8-9.

${ }^{24}$ Ibid., p. 55.

${ }^{25}$ Ibid., p. 3.

${ }^{26}$ Raymond Bellour, Le corps du cinéma: hypnoses, émotions, animalités (Paris: P.O.L éditeur, 2009), pp. 42-43. When discussing the wax museum and the morgue, Bellour references Vanessa R. Schwartz, 'Cinematic Spectatorship before the Apparatus: The Public Taste for Reality in Fin-de-Siècle Paris', in Leo Charney and Vanessa R. Schwartz (eds.), 
Cinema and the Invention of Modern Life (Berkeley: University of California Press, 1995), pp. 297-319. Laura Mulvey analyses similar topics in her book Death $24 x$ a Second: Stillness and the Moving Image (London: Reaktion Books, 2006).

${ }^{27}$ See Jean-Claude Bernardet, 'The Voice of the Other: Brazilian Documentary in the 1970s', in Julianne Burton (ed.), The Social Documentary in Latin America (Pittsburgh: University of Pittsburgh Press, 1990), pp. 93-95. I am indebted to Stefan Solomon for bringing this film and text to my attention.

${ }^{28}$ Peucker, Incorporating Images, p. 112.

${ }^{29}$ Original: 'Cada plano existe só e depois que não acaba.' (translation by Lúcia Nagib) Torquato Neto, 'A Família do Barulho é da pesada', Geléia Geral, Última Hora, March $9^{\text {th }}$, 1972. Available at Memória da Censura no Cinema Brasileiro, 1964-1988:

http://www.memoriacinebr.com.br/arquivo.asp?0120088I003 [accessed: $16^{\text {th }}$ January, 2018] ${ }^{30}$ Stephen Berg, 'Helena Ignez: portrait', in Marina Mottin (ed.), La Femme du bandit. Hommage à Helena Ignez (Catalogue of the $20^{\text {th }}$ Fribourg International Film Festival, 2006), p. 97.

${ }^{31}$ Mikhail Bakhtin, Rabelais and His World, trans. Hélène Iswolsky (Bloomington: Indiana University Press, 1984), p. 317.

${ }^{32}$ Ibid.

${ }^{33}$ See Fernão Ramos, Cinema Marginal (1968-1974): A representação em seu limite (São Paulo: Editora Brasiliense, 1987), pp. 115-126.

${ }^{34}$ Elduque, 'As Belair went by', p. 131.

${ }^{35}$ Randal Johnson, 'Cinema Novo and Cannibalism: Macunaíma', in Randal Johnson and Robert Stam (eds.), Brazilian Cinema (Rutherford / London: Fairleigh Dickinson University Press / Associated University Presses, 1982), p. 186.

${ }^{36}$ Xavier, Allegories of Underdevelopment, p. 5. 
${ }^{37}$ See, for example, Rogério Sganzerla's comments on Macunaíma in Sérgio Cabral, Millôr Fernandes, Jaguar, et al., 'A mulher de todos e seu homem', Pasquim, $5^{\text {th }}$ February 1970; included in Canuto, Rogério Sganzerla - Encontros, p. 58.

${ }^{38}$ I am grateful to Lúcia Nagib and Fabio Camarneiro for bringing this musical connection with the world of Glauber Rocha to my attention.

${ }^{39}$ Xavier, Allegories of Underdevelopment, p. 10. 